\title{
17S2-06＼cjkstart有機カチオントランスポーターOCTN1 の機能特性と組織分布
}

\author{
玉井郁巳 ${ }^{1,2)}$ 、小林大祐 1)、木戸康人 ${ }^{1,2)}$ 、小杉洋平 1)、野沢 敬 ${ }^{1)}$ 、吉田和弘 ${ }^{1)}$ 、 \\ 根津淳一 3)、若山友彦 4)、井関尚一 4)、崔 吉道 1,2)、辻 彰1,2) \\ ${ }^{1)}$ 金沢大 ・薬、 ${ }^{2)} \mathrm{CREST} 、{ }^{3)}$ 中外製薬・創薬資源、4) 金沢大 ・医・第一解剖
}

\begin{abstract}
TISSUE DISTRIBUTION AND FUNCTIONAL CHARACTERIZATION OF ORGANIC CATION/CARNITINE TRANSPORTER OCTN1

Ikumi TAMAI 1,2), Daisuke KOBAYASHI ${ }^{1}$, Yasuto $\mathrm{KIDO}^{1,2)}$, Yohei KOSUGI ${ }^{1)}$, Takashi NOZAWA $^{1)}$, Kazuhiro YOSHIDA ${ }^{1)}$, Jun-ichi NEZU $^{3)}$, Tomohiko WAKAYAMA ${ }^{4}$, Shoichi IZEKI $^{4)}$, Yoshimichi SAI ${ }^{1.2)}$, and Akira TSUJI ${ }^{1.2)}$

1) Faculty of Pharmaceutical Sciences, Kanazawa University, ${ }^{2)}$ CREST, Japan Science and Technology Corporation, ${ }^{3)}$ Chugai Research Institute for Molecular Medicine Inc., and ${ }^{4}$ Kanazawa University, Graduate School of Medical Science.
\end{abstract}

【目的】有機カチオン/カルニチントランスポー ターとして分類される OCTN は、ヒトでは二種 (OCTN1 (SLC22A4) と OCTN2(SLC22A5))の分子 種が存在する。我々はこれまでに、OCTN2 が $\mathrm{Na}^{+}$ 依存的な高親和性カルニチントランスポーターであ り、全身性カルニチン欠乏症原因遺伝子であること を見いだした ${ }^{1,2)}$ 。OCTN2 は Na+非依存的に有機 カチオン性化合物を輸送する活性も有しており、ま た有機カチオン輸送活性の高い腎臓では、近位尿細

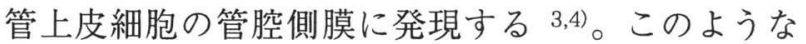
特性から OCTN2 はカルニチンの再吸収と同時に 有機カチオンの分泌にも一部関与するものと考えら れた。さらに、遺伝的に OCTN2 機能を欠損する 動物モデル jVS マウスにおいては、テトラエチルア ンモニウム TEA の分泌クリアランスが低下し、 OCTN2 を介した有機カチオンの分泌が in vivo 実 験系において確認された ${ }^{4)}$ 。しかし、OCTN2 の輸 送特性は、従来からラットやウサギなどの腎臓での 能動分泌に働くことが報告されているカチオントラ ンスポーターの特徵とは必ずしも一致せず、それ以 外のトランスポーター分子の存在を考える必要があ る。有機カチオントランスポーターとして同定され ている OCT (SLC22A1〜3)ファミリーは、ブタ腎 由来 LLCPK1 細胞では管腔側細胞膜における存在 が示唆されているが、その他多くの研究成果として、 側底膜に存在する膜電位依存的なカチオン輸送に働 いているものと考えられる 5)。従って、腎尿細管の 管腔側膜においては、OCTN2 や OCT ファミリー とは異なるトランスポーターが機能するはずである。 我々は既に OCTN ファミリーに属するヒト OCTN1 が TEA 輸送に働き、HEK293 細胞に発現 させた場合の TEA 取り込み活性は、見かけ上酸性 $\mathrm{pH}$ で低下する $\mathrm{pH}$ 依存性を有することを示した ${ }^{6) 。}$

また、TEA のみならず pyrilamine, verapamil, 及 び quinidine などのカチオン性薬物輸送活性も有 していると同時に、弱いながら $\mathrm{Na}^{+}$依存的な carnitine 輸送にも働く7)。しかし、OCTN2 と比 較して carnitine 輸送活性は低く、むしろ生理的に は有機カチオン輸送に働くものと考えられた 7.8)。 同様の TEA 輸送活性はマウスやラット OCTN1 で も観測されている 8,9)。また、ヒト OCTN1 はノー ザン解析では腎臓、筋肉、肺、胎盤、心臓、小腸、 骨髄、ならびに種々癌細胞など、OCT ファミリー に比べ幅広く組織に発現しており、肝臓については
胎览のみに発現する特徴を持つ 6 )。従って、OCT とは異なる役割を持つものと推測される。

一方、OCTN1 遺伝子を含むゲノム領域を OCTN2 遺伝子とともに遺伝子工学的に欠損させたマウスは、 OCTN2 機能のみを欠損させた場合と比較し、脂質 代謝異常やカルニチン補助療法の有効性の低下など、 病態を悪化させることが報告されている10)。従っ て、OCTN2 同様 OCTN1 も異物輸送のみならず生 理的役割を有すると考えられるが、現在まで OCTN1 の薬物動態的・生理学的役割については明 確ではない。

本研究では、OCTN1 のトランスポーターとして の位置づけを明確にする一端として、特に OCTN1 が有するカチオン輸送の意味を明らかにすることを 目的とした。本目的を達成させるためにはまず、組 織内分布ならびに輸送の駆動力など機能特性を見い だすことが重要と考えた。そこで本研究では、特に カチオン性化合物輸送活性が高い腎組織内の分布特 性、ならびにカチオン輸送を生じさせる駆動力につ いて単離膜小胞を用いた解析を試みた。

【方法】 HEK293 細胞にヒト OCTN1 cDNA をトラ ンスフェクションし、G418によって発現細胞を選 別した。コントロールとして発現ベクターpcDNA3 のみをトランスフェクトした細胞株(Mock)も作成し た。複数のクローンについて、OCTN1 mRNA の発 現ならびに $\left[{ }^{14} \mathrm{C}\right] \mathrm{TEA}$ 取り込み活性より細胞株を選 択し、以後の実験に用いた。OCTN1安定発現HEK293 細胞を大量培養し、密度勾配遠心によって膜小胞を 調製した。膜小胞を用いた輸送実験は、迅速濾過法 により行った。免疫組織染色を行うために、マウス OCTN1 のカルボキシ末端ペプチドに対する抗ペプ チド抗体を作成し、抗原ペプチドを用いてアフィニ ティー精製した。マウス腎組織より凍結切片を作成 し、蛍光抗体法により検出を行った。

\section{【結果及び考察】 \\ 1：OCTN1の腎組織内分布特性}

マウス OCTN1、2、及び 3 を各々発現させた HEK293 細胞について作成した精製抗体を用い染色 したところ、OCTN1 を発現させた細胞のみが染色 され、抗体の特異性が確認された。次にマウス腎組 織内における OCTN1 の発現部位を、腎皮質の近位 尿細管上皮細胞管腔側膜に局在している OCTN2 と 
比較した ${ }^{3)}$ 。OCTN1 は腎髄質に比べ腎皮質に強く 発現することが示された。また、腎組織内での発現 部位は、側底膜に存在する $\mathrm{Na}^{+} / \mathrm{K}^{+}-\mathrm{ATPase}$ とは異な り、OCTN2 と一致したことから、管腔側膜と考え られた。糸球体など尿細管以外の発現は見られず、 OCTN1 は OCTN2 同様に、特に近位尿細管上皮細 胞管腔側細胞膜に局在するものと結論づけられた。 本局在性は OCT トランスポーターとは異なるもの であり、以下その意味を明らかにすることを目的と し、機能特性の解析を行った。

\section{2：OCTN1 の膜小胞系による機能特性解析}

OCTN1 を発現させた HEK293 細胞株より膜小胞 を調製し、 $\left[{ }^{14} \mathrm{C}\right] \mathrm{TEA}$ 輸送特性を検討した。

$\left[{ }^{14} \mathrm{C}\right]$ TEA の取り込みは、見かけ上小胞内 $\mathrm{pH}$ を小 胞外 $\mathrm{pH}$ より低くした場合（小胞外へのプロトン勾 配存在下) 、初期取り込み速度が増大する傾向が観 測された。また、その取り込みは OCTN1 をトラン スフェクトしていない Mock 細胞由来膜小胞への取 り込みより高く、本手法により OCTN1を介した $\left[{ }^{14} \mathrm{C}\right] \mathrm{TEA}$ 輸送特性解析が可能であることが確認さ れた（図 1)。以降、本検討においては、小胞内(pH6.0) から小胞外 $(\mathrm{pH} 7.4) へ の ~ \mathrm{pH}$ 勾配存在下における輸送 活性を基準として評洒することにした。

外向きプロトン勾配存在下における $\left[{ }^{14} \mathrm{C}\right] \mathrm{TEA} の$ 初期での取り込み量は、定常状態に比べやや高くな るオーバーシュート現象を示した。既に、HEK293 細胞系で細胞外 $\mathrm{pH}$ を酸性化させた場合、 $\left[{ }^{14} \mathrm{C}\right] \mathrm{TEA}$ 取り込み量は減少することがわかっている6)。本膜 小胞系での結果はそれと対応するものであるが、才 ーバーシュート様現象が観測されたことは、見かけ 上プロトンとの対向輸送を示唆する。

カリウムイオノフォアであるバリノマイシンを利 用して、 $\left[{ }^{14} \mathrm{C}\right] \mathrm{TEA}$ 輸送の膜電位依存性を測定した。 その結果、外向きプロトン勾配存在下での $\left[{ }^{14} \mathrm{C}\right] \mathrm{TEA}$ の初期取り込みは、相対的に小胞内負の膜電位を与 えた時に増加する傾向を示した。一方、プロトン勾 配非存在下での $\left[{ }^{14} \mathrm{C}\right]$ TEA の取り込みは膜電位の影 響を受けなかった。

図 1 では、非標識 TEA をプレロードした膜小胞 への $\left[{ }^{14} \mathrm{C}\right] \mathrm{TEA}$ の取り込みも示している。 $\left[{ }^{14} \mathrm{C}\right] \mathrm{TEA}$
の初期取り込みは、TEA プレロードにより顕著に 増大するオーバーシュートが観測された。即ち、 OCTN1 は、有機カチオンの交換輸送体としても動 くことが示された。従って、OCTN1の輸送活性は、 種々環境因子によって活性が左右されるものと考え られた。

【結論】ヒト OCTN1 は、腎臓においては尿細管 上皮細胞管腔側細胞膜で有機カチオン輸送に働くも のと考えられた。またその駆動力は明確ではないが、 $\mathrm{pH}$ 、膜電位、ならびにカチオン性化合物などによ って影響を受ける夕イプの有機カチオントランスポ ーターとして位置づけられた。即ち、OCTN1はこ のような環境によって活性が変動することから、薬 物動態的にはカチオン性化合物の尿細管分泌あるい は再吸収いずれにも働きうることが示唆された。こ れらの特性は既知ラットやウサギなどの腎における 輸送特性とは完全には一致せず、また OCT とも異 なる特性である。今後は種差も考慮した解析が必要 である。

図 1: OCTN1 発現膜小胞への $\left[{ }^{14} \mathrm{C}\right] \mathrm{TEA}$ 取り込みに 対する pHならびに TEA プレロード効果

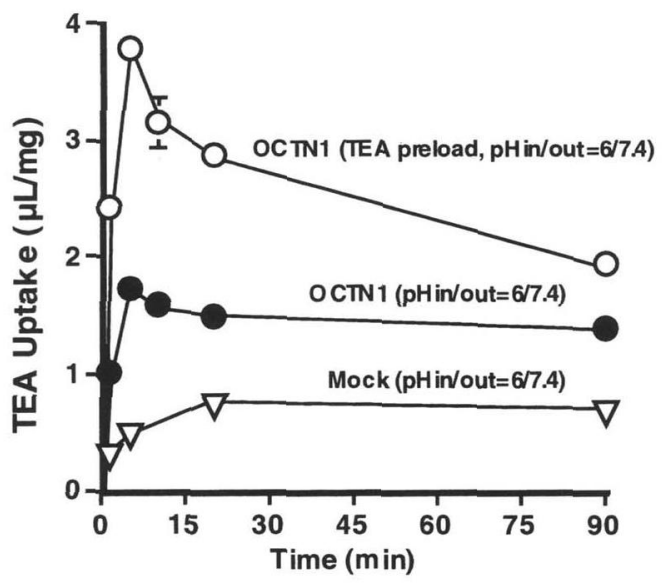

【Abstract】In the present study, we examined the tissue distribution and functional characteristics of a member of organic cation/carnitine transporter family, OCTN1 in human by using membrane vesicles prepared from the HEK293 cells that were stably expressing human OCTN1. Immunohistochemical analysis of mouse OCTN1 in kidney demonstrated that OCTN1 is expressed strongly in epithelial cells of tubular cells in cortex. In epithelial cells, OCTN1 showed differential expression from $\mathrm{Na}^{+} / \mathrm{K}^{+}$-ATPase, which is a basolaterally localized enzyme, and exclusively expressed in the apical membrane of the cells. Membrane vesicles prepared from HEK293 cells that were stably transfected with human OCTN1 showed increased uptake of tetraethylammonium (TEA) compared with that by membrane vesicles form Mock-transfected cells. Uptake of $\left[{ }^{14} \mathrm{C}\right] \mathrm{TEA}$ was apparently $\mathrm{pH}$ dependent and showed overshoot uptake in the presence of outwardly-directed proton gradient. Preloading of unlabeled TEA enhanced the initial uptake of $\left[{ }^{14} \mathrm{C}\right]$ TEA. These kinds of and other studies suggested that OCTN1 may be involved in the pH dependent apical membrane transport of organic cations in kidney and it may also functional as the organic cation/organic cation antiporter. Since OCTN1 is expressed in various tissues, OCTN1 may also contribute in the distribution and/or efflux of cationic compounds in those tissues by being energized by proton or cation gradients across the cellular membranes.

【References】 1) Tamai et al., J. Biol. Chem., 273:20378-20382 (1998). 2) Nezu et al., Nature Genet. 21:91-94 (1999). 3) Tamai et al. Biochim. Biophys. Acta, 1512:273-284 (2001). 4) Ohashi et al., Mol. Pharmacol., 59:358-366 (2001). 5) Sugawara-Yokoo et al., Histochem. Cell Biol. 114:175-180 (2000). 6) Tamai et al.,.FEBS Lett., 419:107-111 (1997). 7) Yabuuchi et al., 289: 768-773 (1999). 8) Tamai et al., J. Biol. Chem., 275:40064-40072 (2000). 9) Wu et al., Biochim. Biophys. Acta, 1466:315-327 (2000). 10) Zhu et al., Proc. Natl. Acad. Sci. USA, 97:1137-1142 (2000). 